\title{
ANTIMEASLES ANTIBODIES IN CHILDREN SUBMITTED TO DIFFERENT VACCINATION SCHEDULES
}

\author{
Solange Artimos de Oliveira, Akira Homma, Léa Camillo-Coura, Maria \\ Lucília P. Loureiro and Maria Teresa G. N. de Almeida
}

\begin{abstract}
In order to study the measles antibody behavior of three vaccination schedules, 684 children were divided into 4 Groups: Group A (341 vaccinated children under the age of one); Group $B$ (101 children at the age of one); Group C 74 children under the age of one and one at the age of one); Group D (163 unvaccinated children with a history of measles in the past - Group control). Children of Group A presented lower rates and $25.9 \%$ of the age group under two did not show any measles antibodies. In Group $B$, all the children presented antibodies. In Group $C$ only $4.0 \%$ did not. In all age groups, the geometric mean HI antibody titers of Group A were lower than the values found in the other groups. The age at vaccination was the factor of greater influence on the results of this study.
\end{abstract}

Key-words: Measles vaccine. Immunology. Epidemiology.

Low immunization coverage is one of the leading causes for the failure of measles elimination programs $^{4}{ }^{5}$. Problems related to the vaccine have also been described ${ }^{33}$. Krugman ${ }^{12}$ believes that these problems can be considered insignificant from the epidemiologic point of view and that adequate immunization is sufficient to protect more than $95 \%$ of vaccinated children, for a longer period.

However, an increase in the number of measles . cases in previously vaccinated children has been described by different authors 57915293133 . The reasons for vaccine failure can be related to: improper storage or handling of the vaccine leading to inactivation of the live virus ${ }^{11} 232429$; neutralization of the vaccine virus by maternal antibodies or those artificially administered (gamma globulin) $)^{2172829}$ or "primary vaccine failure", in about $5 \%$ of the vaccinees ${ }^{23}$.

\footnotetext{
Disciplina de Doenças Infecciosas e Parasitárias, Universidade Federal Fluminense, Niterói, RJ, Bio-Manguinhos, Fundação Oswaldo Cruz, Rio de Janeiro, RJ, Departamento de Medicina Preventiva, Universidade Federal do Rio de Janeiro, Rio de Janeiro, RJ, and Secretaria Municipal de Saúde, Niterói, RJ, Brasil.

Granted by FINEP - Process 04.03.85-0459-00.

Address for correspondence: Profa. Solange Artimos de Oliveira. Disciplina de Doenças Infecciosas e Parasitárias, Hospital Universitário Antonio Pedro. R. Marquês do Paraná 303, $2^{\circ}$ andar. 24033-900 Niterói, RJ, Brasil.

Fax: (021) 717-4459.

Recebido para publicação em 23/11/92.
}

Currier and associates ${ }^{6}$ consider the age at vaccination as the only factor from the previously related ones capable of causing a significant increase in measles attack rate in vaccinated children.

The objective of the present research was to study measles antibodies, in the years following vaccination, of previously vaccinated children in the Public Health Units of the Municipalities of Niterói and São Gonçalo, State of Rio de Janeiro, correlating the results with the number of doses of vaccine and the child's age at vaccination.

\section{MATERIAL AND METHODS}

Study population. The sample chosen at random was 684 children who attended for various reasons some selected primary health units, public or private, from March 1985 to February 1986, in the Municipalities of Niterói and São Gonçalo, State of Rio de Janeiro.

Study design. Children were divided into three groups according to their ages at measles vaccination and number of doses received (confirmed by vaccination cards). A group of unvaccinated children with a history of measles in the past based on the criteria established by the Centers for Disease Control, i. e., fever, cough, typical rash lasting three or more days and catarrhal symptoms served as controls.

Group A, comprising 341 children who had received a single one dose under one year of age. 
Oliveira SA, Homma A, Camillo-Coura L, Loureiro MLP, Almeida MTGN. Antimeasles antibodies in children submitted to different vaccination schedules. Revista da Sociedade Brasileira de Medicina Tropical 26:77-82, abr-jun, 1993.

Group B, comprising 101 children who had received a single dose at the age of one.

Group C, comprising 79 children who had received one dose under one year of age and a second dose at the age of one.

Group D, comprising 163 unvaccinated children with a history of measles in the past.

The parents were always asked to consent to the drawing of a blood sample from their children.

Laboratory tests. Blood samples were obtained by venopuncture. After centrifugation the sera were stored at $-20^{\circ} \mathrm{C}$. Specific antibodies for measles virus were detected through hemagglutination inhibition test $(\mathrm{HI})$, and, when titers were below 8 , a virus neutralization test (NT) was performed ${ }^{19} 26$. The titer was considered as the reciprocal of the end-point dilution.

The children who had HI titers below 8 and NT negative were considered as susceptible to measles.

Statistical analysis. Frequency distributions were analysed by the chi-square test and the differences considered significant at the 0.01 level. The geometric mean HI antibody titers were calculated and a t-test (Student) was carried out to compare these titers ${ }^{22}$.

\section{RESULTS}

Group A. It was found that the frequency of HI titers below 8 diminished throughout the years in the group (Table 1). In the age group under 2 years of age, $48.2 \%$ no measles antibody was detected. However, in the 10-15 years age group this percentage fell to $4.5 \%$. It was observed that the highest titers were found in children vaccinated long ago (Table 2).

Better results were found when the NT test was used in the negative $\mathrm{HI}$ cases but even so $25.9 \%$ and $18.3 \%$ of the children of Group A had no detectable antibody in the age groups under 2 years and 2-4 years of age, respectively (Figure 2). Less frequently this fact was also detected in the following age groups. Of all the cases studied in Group A only $8.2 \%$ had been vaccinated before 9 months of age.

Group B. The results of this group are shown in Table 1. It can be seen that the percentages of cases with HI titers below 8 diminished throughout the years. However, the difference among them was not so great, i. e.: under 2 years: $13.0 \% ; 2-4$ years: $11.8 \%$ and $5-9$ years of age: $8.2 \%$. Also, important variations were not observed among the geometric mean of the $\mathrm{HI}$ antibody titers as calculated for each age group (Table 2).
As in Group A, it was verified that the frequency of children with detectable antibodies in Group B increased when the NT was employed to evaluate the HI negative samples (Table 1). Measles antibodies were found in all children under 2 years of age and, in the age groups of 2-4 years and 5-9 years of age, in $94.1 \%$ and $96.7 \%$, respectively (Figure 2).

Group C. In this group the percentage of cases with $\mathrm{HI}$ titers below 8 increased with age, being $8.0 \%$ in children under 2 years of age and $17.2 \%$ in those between 2-4 years of age (Table 1). However, the geometric mean of $\mathrm{HI}$ antibody titer was nearly the same in the two age groups studied (Table 2).

A similar result was observed when the NT was employed in the HI negative samples. Measles antibodies were detected in $96.0 \%$ of the age groups above mentioned.

Group D. As indicated in Table 1, in 159 cases out of 163 of children with a past history of measles $(97.5 \%)$, specific antibodies were detected either by HI or NT. The geometric mean HI antibody titers declined throughout the years after the disease and this was more pronounced until 4 years of age.

Comparative study. In the age group under 2 years, the value of the geometric mean HI antibody titers found in Group A (9.25) were nearly three times lower than those observed in Groups B (25.10) and $C$ (26.35). In the following age groups, this difference diminished mainly due to the elevation of the Group A mean titers.

The percentage of measles antibodies measured by HI or NT (Figure 2) were also lower than those found in Groups B and C. In the age group under 2 years, all the children of Group B and $96 \%$ of Group $C$ had measles antibodies against only $74.1 \%$ of Group A. In the following time intervals studied those differences decreased although a statistically significant difference between Group $A$ and $B$, in the age group 2-4 years $\left(x^{2}: 10.78-P<0.01\right)$ still existed.

The geometric mean $\mathrm{HI}$ antibody titers of Group D (Figure 1) were always higher than the other groups, mainly when compared to the value found in Group A. This difference was more pronounced in the age groups 2-4 years and 5-9 years of age. In relation to the frequency of antibodies measured by $\mathrm{HI}$ and NT (Figure 2) it was also verified that the percentages were higher in the children of Group D than those of Group A. This fact was not observed when Group $D$ was compared to the other groups of vaccinees (B and C). 
Oliveira SA, Homma A, Camillo-Coura L, Loureiro MLP, Almeida MTGN. Antimeasles antibodies in children submitted to different vaccination schedules. Revista da Sociedade Brasileira de Medicina Tropical 26:77-82, abr-jun, 1993.

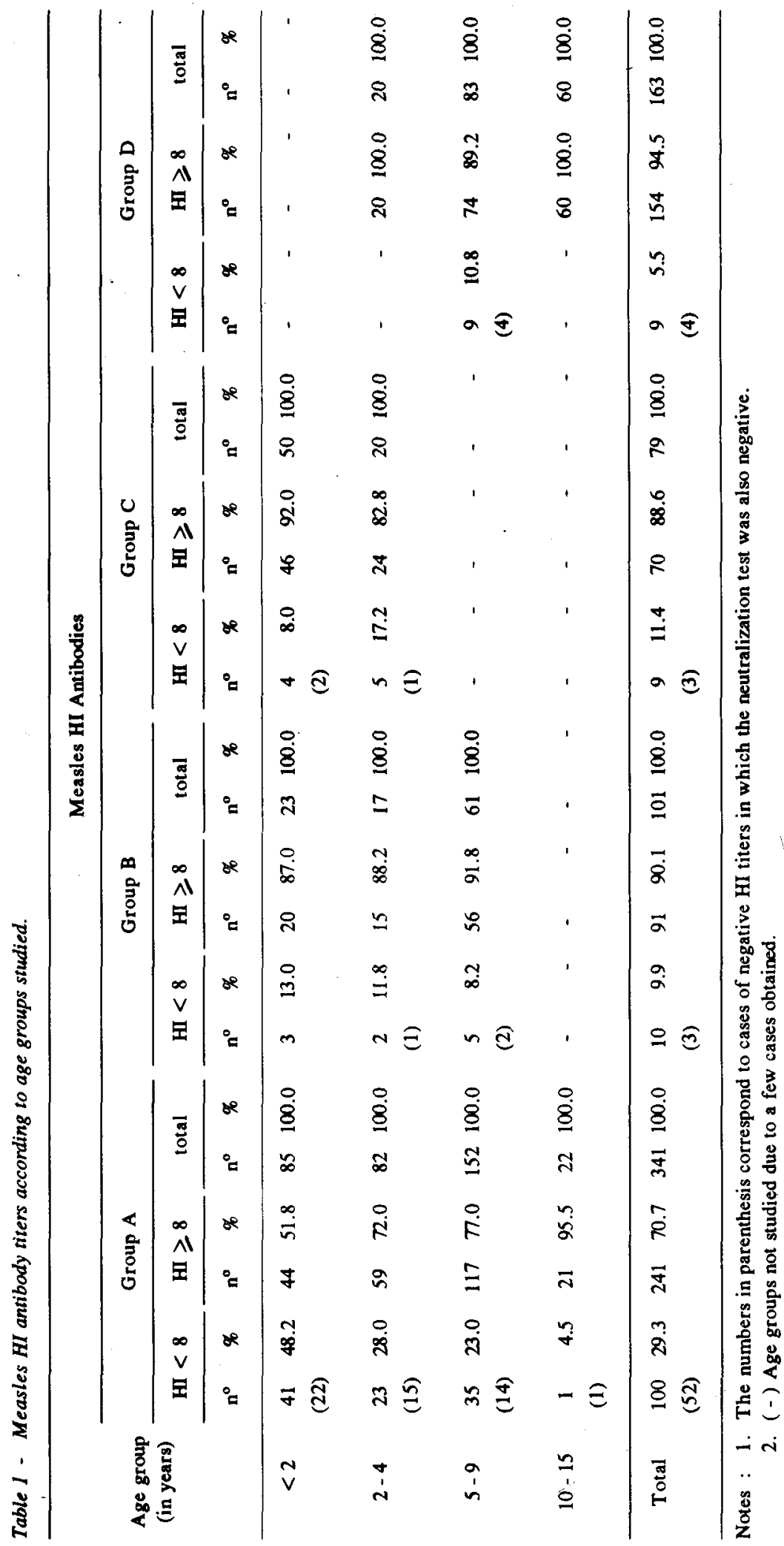


Oliveira SA, Homma A, Camillo-Coura L, Loureiro MLP, Almeida MTGN. Antimeasles antibodies in children submitted to different vaccination schedules. Revista da Sociedade Brasileira de Medicina Tropical 26:77-82, abr-jun, 1993.

Table 2 - Geometric mean HI antibody titers of the groups according to age studied.

\begin{tabular}{rrrcc}
\hline $\begin{array}{c}\text { Age group } \\
\text { (in years) }\end{array}$ & \multicolumn{4}{c}{ Geometric mean HI antibody titer } \\
\cline { 2 - 5 } & $\begin{array}{c}\text { Group } \\
\text { A }\end{array}$ & $\begin{array}{c}\text { Group } \\
\text { B }\end{array}$ & $\begin{array}{c}\text { Group } \\
\text { C }\end{array}$ & $\begin{array}{c}\text { Group } \\
\text { D }\end{array}$ \\
\hline$<2$ & 9.25 & 25.10 & 26.35 & - \\
$2-4$ & 22.31 & 37.53 & 26.90 & 87.42 \\
$5-9$ & 18.38 & 27.85 & - & 44.32 \\
$10-15$ & 34.05 & - & - & 47.50 \\
\hline
\end{tabular}

Note: ( - ) Age groups not studied due to few cases obtained.

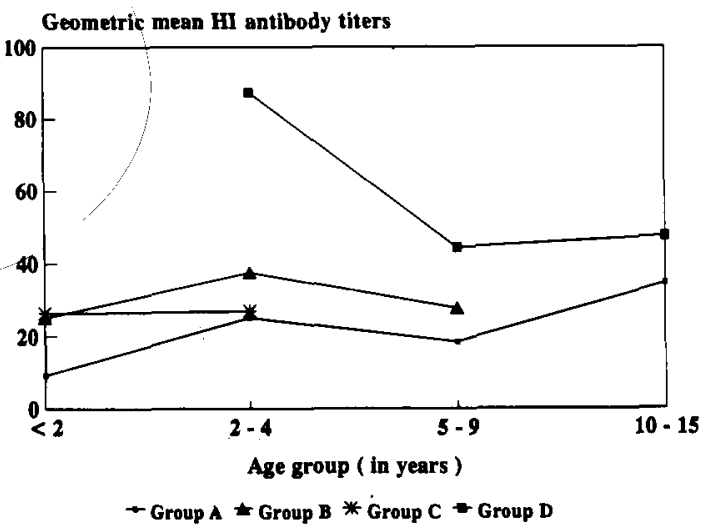

Figure 1 - Measles Hi antibody titers values according to age groups studied.

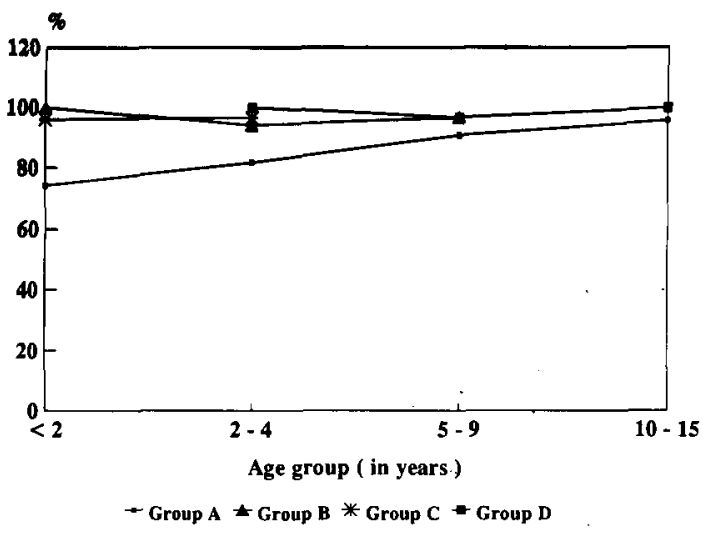

Figure 2 - Measles antibodies prevalence percentages according to age group.

\section{DISCUSSION}

Studies made to evaluate measles immunity in children vaccinated at less than one year of age have shown that about $45 \%$ of them had HI antibody titers below $10^{32}$. Apart from this, more than $40 \%$ of vaccine failures are related in subjects that received this product in that age group ${ }^{561533}$. These children presented lower seroconversion rates and antibody titers when compared to those that vaccinees with one year of age or older ${ }^{1} 101828$. In Halsey's 8 opinion it is possible that the former group is more capable to lose their antibodies throughout future years.

In the present research it was shown that the percentage of measles antibodies measured by $\mathrm{HI}$ and NT in children vaccinated under one year (Group A) was always lower than those vaccinated at one year of age (Group B). In the age group under 2 years, all Group B children had measles antibodies in contrast to $74.1 \%$ of Group A. Although this difference had diminished throughout the years, it was significant $(\mathrm{P}<0.01)$ up to the age of four.

Also the geometric mean $\mathrm{HI}$ antibody titers of Group A were always lower than those found for Group B in the age groups studied, mainly in children under 2 years old. While the pattern of the mean titer of $\mathrm{HI}$ antibodies in Group C (vaccinated with two doses) was similar to that verified for Group B.

The results of this research suggest that the age at vaccination can be considered as a significant factor in the frequency of measles antibody in the group studied. Probably this fact can be due to the presence of maternal antibodies in infants vaccinated before the age of one. It was also found that the frequency of antibody and the geometric mean $\mathrm{HI}$ antibody titer of Group A progressively increased throughout the years while the values of Group B and $C$ remained stable, with little variations. Subclinical reinfection with measles virus in Group A children could explain this finding since overt clinical disease had been denied by parents in all the cases studied.

In large clusters of vaccinees antibody titers may change according to the intensity of wild virus circulation. In closed populations these titers progressively decrease ${ }^{12}$ but in open populations the antibody levels remain high, presumably as a 
Oliveira SA, Homma A, Camillo-Coura L, Loureiro MLP, Almeida MTGN. Antimeasles antibodies in children submitted to different vaccination schedules. Revista da Sociedade Brasileira de Medicina Tropical 26:77-82, abr-jun, 1993.

result of re-exposure to wild virus ${ }^{13} 1427$.

Ruiz-Gomez and associates ${ }^{27}$ established a correlation between the time elapsed between vaccination and blood collection. Their results are similar to those presented in the present paper, i. e., increase in the frequency of measles antibodies throughout the years. However, they did not find a parallel increase of geometric mean titers. The authors believe that this finding could be due to subclinical reinfections with the wild virus.

Antibody levels after vaccination are lower than those found in subjects who had natural measles ${ }^{3}$ 925 . This difference is due to attenuation of wild virus during vaccine production ${ }^{30}$.

In our study vaccinated children (Groups A, B and $C$ ) were also compared to those with a history of measles in the past (Group D). The geometric mean HI antibody titers of Group D were always higher than the values found for the vaccinees. However, this difference was more pronounced when Group D was compared to Group A, mainly during the first five years after vaccination. These findings were not affected by the age at vaccination and doses of vaccine received.

Moreover, alterations in measles vaccine quality in use in health units could also have contributed to the results above related. Oliveira and associates, in $1986^{20}$ and, again in 1990 (Oliveira SA and associates: data not published), carried out an investigation to evaluate the basic procedures involved in the storage of measles vaccine in public health units of the same Municipalities studied here. The first research showed inadequacy and lack of uniformity, at regional and local levels, concerning conditions of vaccine storage as well as insufficient training of health workers. All vaccine samples titers were well under the minimal recommended potency by the manufacturers. Four years later, despite the improvement of the cold chain when compared to the former evaluation, $55.2 \%$ of the vaccine samples were still under the minimal recommended potency.

The age at vaccination was the factor that mostly influenced the results of this project. So, based on our data and those from literature 561516 213233 we suggest for developing countries a two dose vaccination schedule against measles that includes an early first dose at nine months of age and revaccination after 12 months of age.

\section{RESUMO}

Com o objetivo de estudar o comportamento dos anticorpos contra o sarampo após a vacinação, 684 crianças foram divididas em 4 grupos: Grupo A $(341$ crianças vacinadas abaixo de um ano de idade); Grupo $B$ (101 crianças com um ano de idade); Grupo C 179 crianças com 2 doses, uma abaixo de um ano e outra com um ano de idade); Grupo D (163 crianças não vacinadas com história prévia de sarampo - grupo controle). Verificou-se que as crianças do Grupo A apresentavam baixas taxas de anticorpos protetores, sendo que em $25,9 \%$ delas, na faixa etária de menores de dois anos, tais anticorpos não foram detectados, contra nenhum caso do Grupo $C$ e 4,0\% do Grupo B. As médias geométricas dos títulos de anticorpos HI do Grupo A foram inferiores às encontradas para os outros grupos. $A$ idade da vacinação foi o fator de maior influência nos resultados deste estudo.

Palavras-chaves: Vacina contra o sarampo. Imunidade. Epidemiologia.

\section{ACKNOWLEDGEMENTS}

The technical advice provided by the staff of Setor de Controle Microbiológico de Vacinas Virais de Bio-Manguinhos, Fundação Oswaldo Cruz is gratefully acknowledged.

\section{REFERENCES}

1. Albrecht P, Ennis FA, Saltzman EJ, Krugman $\mathbf{S}$. Persistence of maternal antibody in infants beyond 12 months. Mechanism of measles vaccine failure. The Journal of Pediatrics 91:715-718, 1977.

2. Arberter AM, Arthur JH, Blakeman GJ, Mclntosh K. Measles immunity: reimmunization of children who previously received lived measles vaccine and gamma globulin. The Journal of Pediatrics 81:737741, 1972.

3. Calafiori CD, Nader PR, Lepon ML, Nankervis GA, Casey H, Warren RJ. Attenuated measles virus vaccine dosage study. Cleveland, Ohio, 1966. American Journal of Epidemiology 87:247-252, 1968.

4. Centers for Disease Control. Morbidity Weekly Report. Measles - United States, First 26 weeks, 1986. Morbidity and Mortality Weekly Report 36:22, 1986.

5. Cherry JD, Feigin RD, Lobes Jr LA, Hinthorn DR, Shackelford PG, Shirley RH, Lins RD, Choi SC. Urban measles in the vaccine era: A clinical, epidemiologic, and serologic study. The Journal of Pediatrics 81:217-230, 1972. 
Oliveira SA, Homma A, Camillo-Coura L, Loureiro MLP, Almeida MTGN. Antimeasles antibodies in children submitted to different vaccination schedules. Revista da Sociedade Brasileira de Medicina Tropical 26:77-82, abr-jun, 1993.

6. Currier RW, Hardy GE, Conrad JL. Measles antibody in previously immunized children. The need of revaccination. American Journal Disease of Children 124:53-57, 1972.

7. Gustafson TL, Lievens AW, Brunelli PA, Moellenberg RG, Buttery CMG, Sehulster LM. Measles outbreak in a fully immunized second school population. The New England Journal of Medicine 316:771-774, 1987.

8. Halsey NA. The optimal age for administering measles vaccine in developing countrics. In: Halsey NA, De Quadros CA (eds) Recent advances in immunization. Pan American Health Orga nization, Washington DC p.4-13, 1983.

9. Judelsohn R, Fleissner ML, O'Mara DJ. School based measles outbreaks: Correlations of age at immunization with risk of disease. American Journal Public Health 70:1162-1165, 1980.

10. Kalis JM, Quie PG, Balfour Jr HH. Measles (rubeola) susceptibility among elementary school children. American Journal of Epidemiology 101:527-531, 1975.

11. Krugman RD, Meyer BC, Parkman PD, Wittle JJ, Meyer HM. Impotency of live-virus vaccines as a result of improper handling in clinical practice. The Journal of Pediatrics 91:512-514, 1974.

12. Krugman S. Present status of measles and rubella immunization in the United States: A medical progress report. The Journal of Pediatrics 78:1, 1971.

13. Krugman S, Giles JP, Friedman H. Studies on immunity to measles. The Journal of Pediatrics 66:471-488, 1965 .

14. Linnemann $\mathrm{J} r \mathrm{CC}$. Measles vaccine: immunity, reinfection and revaccination. American Journal of Epidemiology 97:365-371, 1973

15. Linnemann Jr CC, Rotte TC, Schiff GM, Youtsey JL. A seroepidemiologic study of a measles epidemic in a highly immunized population. American Journal of Epidemiology 95:238-246, 1972.

16. Lopes $\mathrm{MH}$, Mendonça JS, Pannuti CS, Albrecht $\mathrm{P}$, Biancalana MLN, Mantese OC, Corrêa JF, Amato Neto $V$. Measles vaccination: influence of age on its efficacy. Revista do Instituto de Medicina Tropical de São Paulo 31:322-327, 1989.

17. Maulitz RM, Conrad JL. A measles outbreak in a New England community. American Joumal Disease of Children 131:57-59, 1977.

18. Ministérios de la Salud de Brasil, Costa Rica, Chile, Ecuador y la Organización Panamerica de la Sallud. Indices de conversión sérica y títulos de anticuerpos inducidos por la vacuna antisarampionosa en niños lationoamericanos de seis a doce meses de edad. Boletin de la Oficina Sanitaria Panamericana 94:224$238,1983$.

19. Oliveira SA. Contribuição ao estudo da imunidade contra o sarampo em pessoas vacinadas e não vacinadas nos Municípios de Niterói e São Gonçalo. Tese de Doutorado, Faculdade de Medicina da Universidade Federal do Rio de Janeiro, Rio de Janeiro, 1989

20. Oliveira SA, Homma A, Mahul DC, Loureiro MLP, Camillo-Coura L. Avaliação das condições de estocagem da vacina contra o sarampo nas unidades sanitárias dos Municípios de Niterói e São Gonçalo, Estado do Rio de Janeiro. Revista do Instituto de Medicina Tropical de São Paulo 33:313-318, 1991.

21. Onoja AL, Adu FD, Tomori $O$. Evaluation of measles vaccine programme conducted in two separate health centres. Vaccine 10:49-52, 1992.

22. Pimentel Gomes F. Curso de Estatística Experimental. $5^{a}$ edição, Nobel, São Paulo, 1973.

23. Plotkin SA. Failures of protection by meas iss vaccine. The Journal of Pediatrics 82:908-911, 1973.

24. Pral MM, Woe Fang FL, Rizzo E. Potency control of live, attenuated vaccines against measles used in children vaccinations in the State of São Paulo, Brasil (1976-1980). Revista do Instituto de Medicina Tropical de São Paulo 24:1-5, 1982.

25. Rosen L. Hemagglutination and hemmagglutination - inhibition with measles virus. Virology 13:139$141,1961$.

26. Ruiz-Gómez J, Burgos YS, Romero PFA, Arrayales F. Respuesta a la vacuna antisarampión al ser aplicada a diferentes edades. Salud Pública México 20:339-342, 1978.

27. Schluederberg A, Lamm SH, Landrigan PJ, Black FL. Measles immunity in children vaccinated before one year of age. American Journal of Epidemiology 97:402-409, 1973.

28. Secretaria de Estado de Saúde e Higiene \& Fundação Oswaldo Cruz. Avaliação do Programa de Imunizações do Estado do Rio de Janeiro. Escola Nacional de Saúde Pública, Rio de Janeiro, 1983.

29. Shasby M, Shope TC, Downs H, Herrmann KL, Polkowski J. Epidemic measles in a highly vaccinated population. The New England Journal of Medicine 296:585-589, 1977.

30. Weibel RE, Buynak EB, Stokes Jr J, Hilleman MR. Persistence of immunity following monovalent and combined live measles, mumps, and rubella virus vaccines. Pediatrics 51:467-475, 1973.

31. Weiner LB, Corwir RM, Nieburg PI, Feldman HA. A measles outbreak among adolescents. The Journal of Pediatrics 90:17-20, 1977.

32. Wilkins J, Wehrle PF, Portnoy B. Live further attenuated rubeola vaccine. Serologic responses among term and low birth weight infants. American Journal Disease of Children 123:190-192, 1972.

33. Wyll SA, Witte JJ. Measles in previously vaccinated children. An epidemiological study. The Journal American Medical Association 216:1306-1310, 1971. 